\title{
Molecular tectonics: control of packing of luminescent networks formed upon combining bisamidinium tectons with dicyanometallates
}

\author{
Pierre Dechambenoit, Sylvie Ferlay*, Nathalie Kyritsakas and Mir Wais Hosseini* \\ s Received (in XXX, XXX) Xth XXXXXXXXX 200X, Accepted Xth XXXXXXXXX 200X \\ First published on the web $X$ th $X X X X X X X X X 200 X$ \\ DOI: $10.1039 / \mathbf{b 0 0 0 0 0 0 x}$
}

Abstract: The combination of bisamidinium dicationic tectons $\left[\mathrm{X}-2 \mathrm{H}^{+}\right](\mathrm{X}=2-4)$ bearing four alkyl chains of variable lengths with linear $\left[\mathrm{M}(\mathrm{CN})_{2}\right]^{-}(\mathrm{M}=\mathrm{Ag}$ or $\mathrm{Au})$ anions leads to the

10 formation of luminescent crystalline materials. The recognition mode, the connectivity patterns

between cationic and anionic tectons leading to the formation of either 1- or 2-D networks as well

as the packing of the latter are presented and discussed.

\section{Introduction}

Molecular tectonics ${ }^{1}$, a branch of supramolecular 15 chemistry $^{2}$ and supramolecular synthesis ${ }^{3}$ deals on one hand with the description of molecular crystals as periodic entities or networks ${ }^{4}$ resulting from specific interactions between molecular components ${ }^{5}$ and on the other hand, is concerned with the generation of periodic architectures in the crystalline ${ }_{20}$ phase through the design of tectons ${ }^{6}$ and molecular recognition patterns between tectons as nodes of the network. Concerning the latter, among various possible intermolecular interactions, H-bonding, owing to its rather directional nature, ${ }^{7}$ has been widely used. However, this type of 25 interactions is rather weak and can be strengthened by addition of less directional electrostatic charge-charge interactions (charge-assisted H-bond). ${ }^{8}$ Another important characteristic defining molecular networks is their dimensionality which results from the number of translations 30 of nodes in space. Indeed a single translation leads to a 1-D network whereas two and three translations in different space directions generate 2- and 3-D networks. For both 1- and 2-D networks, the control of their packing in the solid state leading to the formation of crystals is an important challenge.

35 Another challenge in molecular tectonics is to design functional networks in the solid state displaying physical and/or chemical properties resulting from the specific interactions between tectons leading to their controlled arrangements. The design of crystalline solids displaying an 40 induced property absent at the level of the individual tectons but expressed in the self-assembled architecture is of particular interest.

Here we report on the design and generation of a series of hybrid luminescent crystals resulting from combinations of 45 dicyanometallate monoanions and bisamidinium dicationic tectons bearing four alkyl chains of variable length forming charge-assisted H-bonded networks and on the modulation of the distance between networks by the nature of the substituents localised on the organic tecton.

\section{${ }_{50}$ Results and discussion}

We are involved for some time now in the design and formation of molecular network based on charge assisted $\mathrm{H}$ bonding using bisamidinium type tectons. ${ }^{9}$ Using a variety of dicationic organic tectons, we have reported the formation of ${ }_{55}$ purely organic networks using carboxylates ${ }^{10}$ or sulfonates ${ }^{11}$ as anionic partners. Furthermore, upon combining bisamidinium based tectons with polythiocyanoatometallate, ${ }^{12}$ polyoxalatometallate $^{13}$ or polycyanometallate ${ }^{14}$, hybrid molecular networks have been obtained. Some of the reported ${ }_{60}$ crystals exhibit physical properties such as luminescence ${ }^{15}$ or porosity ${ }^{16}$ or liquid crystalline behaviour. ${ }^{17}$

We have demonstrated that the combination of the tecton 2$2 \mathrm{H}^{+}($Scheme $)$with $\left[\mathrm{M}(\mathrm{CN})_{4}\right]^{2-}(\mathrm{M}=\mathrm{Ni}, \mathrm{Pd} \text { or } \mathrm{Pt})^{18}$ or $\left[\mathrm{M}(\mathrm{CN})_{6}\right]^{3-}(\mathrm{M}=\mathrm{Co}, \mathrm{Fe} \text { or } \mathrm{Cr})^{19}$ leads to the formation of 1${ }_{65}$ and 2-D H-bonded networks respectively with the same type of recognition patterns as for $1-2 \mathrm{H}^{+} .{ }^{14 a}$ Importantly, by comparing the packing mode of $1-\mathrm{D}$ networks obtained by associating tectons $\mathbf{1}-2 \mathrm{H}^{+}$or $\mathbf{2}-2 \mathrm{H}^{+}$with $\left[\mathrm{M}(\mathrm{CN})_{4}\right]^{2-}$, we have shown that the distance between 1-D networks in the crystal 70 can be modulated by the nature of the substituents on the organic tecton ( $\mathrm{H}$ for $1-2 \mathrm{H}^{+}$and propyl for $\left.2-2 \mathrm{H}^{+}\right) .{ }^{18}$

Scheme

${ }_{75}$ Furthermore, the combination of $\mathbf{1}-2 \mathrm{H}^{+}$with $\left[\mathrm{M}(\mathrm{CN})_{2}\right]^{-}(\mathrm{M}=$ $\mathrm{Ag}$ or $\mathrm{Au}$ ) leads also to the formation of 1-D networks however with a different connectivity pattern (Fig. 1a). ${ }^{15}$ 
For the latter case, it appeared interesting to investigate the role played by the alkyl substituents on the packing of 1-D networks in the crystalline phase and thus on the modulation of M-M distance (d) between metal centres belonging to 5 consecutive networks (Fig. 1b).

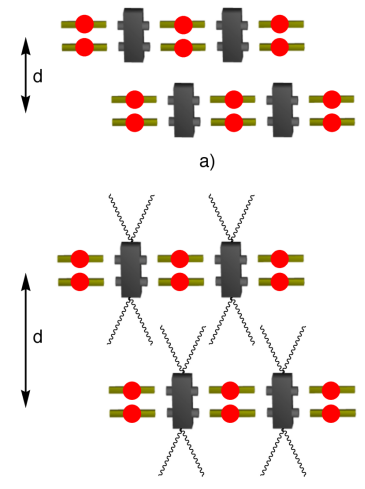

b)

Fig. 1: Schematic representation of the formation of 1-D networks and their packing in the solid state for combinations of dicyanometallate and tecton $1-2 \mathrm{H}^{+}$(a) and its tetraalkylated

10 analogues $\mathbf{X}-2 \mathrm{H}^{+}(\mathbf{X}=2-4)(b)$.

Design of tectons $\mathrm{X}-2 \mathrm{H}^{+}(\mathrm{X}=1-4)$ : Bis-amidinium $\mathrm{X}-2 \mathrm{H}^{+}$ $(\mathrm{X}=1-4)$ (Scheme 1) are analogous dicationic tetra H-bond donor tectons. They are based on two cyclic amidinium moieties connected by a phenyl spacer. The latter was 15 introduced in order to impose the distance between the two acidic $\mathrm{H}$ atoms on the same face of the tecton and to restrain its conformational space. Furthermore, the presence of the aromatic spacer, owing to the electronic conjugation with the amidinium group, enhances considerably the stability of the 20 tecton towards hydrolysis. Tectons $\mathbf{X}-2 \mathrm{H}^{+}(\mathrm{X}=1-4)$ diverge only by the nature of the substituents on the cyclic amidinium units. Indeed, whereas for the parent compound $1-2 \mathrm{H}^{+}$no substituent is present, in the case of compound $\mathbf{X}-2 \mathrm{H}^{+}(\mathrm{X}=2$ 4 ), the position 3 of each cyclic amidine moiety bears two 25 alkyl groups of different length $\left(\mathrm{C} 3\right.$ for $2-2 \mathrm{H}^{+}, \mathrm{C} 6$ for $3-2 \mathrm{H}^{+}$ and $\mathrm{C} 12$ for $4-2 \mathrm{H}^{+}$). It is worth noting that these substituents are rather remote from the H-bond donor sites and thus should not interfere with the recognition processes with dicyanometallates.

30 Synthesis of tectons $\mathrm{X}-2 \mathrm{H}^{+}(\mathrm{X}=3-4)$ : The synthesis of 1$2 \mathrm{H}^{+10,16}$ and $\mathbf{2}-2 \mathrm{H}^{+18}$ was previously reported. The preparation of compounds $3-2 \mathrm{H}^{+}$and $4-2 \mathrm{H}^{+}$(see experimental section) was achieved starting with malononitrile $\mathbf{5}$, which was reacted, in anhydrous THF, with 1-bromoalkane (hexane for ${ }_{35} 3-2 \mathrm{H}^{+}$and dodecane for $4-2 \mathrm{H}^{+}$) in the presence of sodium hydride affording the dinitrile 6 and 7 in 27 and 74\% yield respectively. ${ }^{20}$ The dinitrile 6 and 7 were reduced upon treatment with borane in dry THF into the diamine 8 and 9 in $90 \%$ yields in both cases. The condensation of 8 and 9 with 40 1,4-dicyanobenzene in the presence of $\mathrm{P}_{2} \mathrm{~S}_{5}{ }^{21}$ afforded the desired compounds 3 and $\mathbf{4}$ in 21 and $15 \%$ yields respectively.

\section{Structural investigations}

For all structural investigations by X-ray diffraction on single 45 crystal, crystallographic data are given in table 1 .
Structure of $\left[3-2 \mathrm{H}^{+}\right]\left[\mathrm{Cl}^{-}\right]_{2}$ in the crystalline phase: The solid structure of the hydrochloride salt of $\mathbf{3}$ with the following formula $\mathrm{C}_{38} \mathrm{H}_{68} \mathrm{~N}_{4} \mathrm{Cl}_{2} \cdot 2 \mathrm{H}_{2} \mathrm{O}$ was investigated by $\mathrm{X}$-ray diffraction on a single crystal (Fig. 2, Table 1). The crystal is 50 composed of $3-2 \mathrm{H}^{+}$, two $\mathrm{Cl}^{-}$anions and two water molecules. For the cationic part $3-2 \mathrm{H}^{+}$, the $\mathrm{C}-\mathrm{N}$ distances vary between $1.310(3)$ and $1.322(3) \AA$ with the $\mathrm{N}-\mathrm{C}-\mathrm{N}$ angle of $121.0(2)$ and $121.1(2)^{\circ}$. These values are close to those observed for the analogous compounds $\left[1-2 \mathrm{H}^{+}\right]\left[\mathrm{Cl}^{-}\right]_{2}{ }^{10,16}$ and $\left[2-2 \mathrm{H}^{+}\right]\left[\mathrm{Cl}^{-}\right.$ $\left.{ }_{55}\right]_{2}{ }^{18}$ Both six-member amidinium cycles adopt a half chair conformation and are almost parallel and tilted with respect to the phenyl ring with the NCCC dihedral angle varying between $38.53(27)$ and $42.51(38)^{\circ}$. The average distance of ca. $7.02 \AA$ between nitrogen atoms belonging to two 60 amidinium units $3-2 \mathrm{H}^{+}$localised on the same side of the molecule is in accordance with what was observed for analogous compounds $\left[\mathbf{1}-2 \mathrm{H}^{+}\right]\left[\mathrm{Cl}^{-}\right]_{2}{ }^{10,16}$ and $\left[2-2 \mathrm{H}^{+}\right]\left[\mathrm{Cl}^{-}\right]_{2}{ }^{18}$ The four hexyl chains adopt an extended conformation (Fig.2). Two $\mathrm{H}_{2} \mathrm{O}$ molecules and $\mathrm{Cl}^{-}$anions are located 65 between consecutive dicationic units (Fig. 2). The two water molecules are interconnected through $\mathrm{H}$-bonds $\left(\mathrm{d}_{\mathrm{O}-\mathrm{O}}=\right.$ 2.813(3) $\AA$ ) and form a pair. They are further H-bonded with both the dicationic units $\left(\mathrm{d}_{\mathrm{O}-\mathrm{N}}=2.813(3) \AA\right.$ and $\left.2.898(3) \AA\right)$ and chloride anions $\left(\mathrm{d}_{\mathrm{O}-\mathrm{Cl}}=3.117(2) \AA\right.$ and 3.164(2) $\AA$ ). The 70 water pair, by bridging consecutive dicationic tectons, leads thus to the formation of a 1-D network (Fig. 2). The $\mathrm{Cl}^{-}$anions also interact with the dication through $\mathrm{H}$-bonds $\left(\mathrm{d}_{\mathrm{N}-\mathrm{Cl}}=\right.$ 3.095(2) and 3.136(2) $\AA$ ).

The analogous hydrochloride salt $\left[2-2 \mathrm{H}^{+}\right]\left[\mathrm{Cl}^{-}\right]_{2}$ also 75 crystallises in the presence of water molecules (formula $\mathrm{C}_{26} \mathrm{H}_{44} \mathrm{~N}_{4} \mathrm{Cl}_{2} \cdot 2 \mathrm{H}_{2} \mathrm{O}$ ) and shows the same type of connectivity i.e. formation of a $\mathrm{H}$-bonded water dimer interconnecting two chloride anions and interacting with the cationic unit. ${ }^{18}$

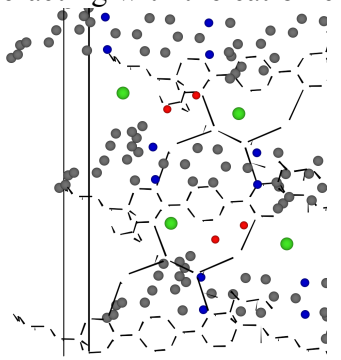

80 Figure 2: A portion of the crystal structure of $[3-2 \mathrm{H} \cdot][\mathrm{Cl}]_{2}$ showing the formation of a 1-D H-bonded network resulting from interconnection of consecutive salts $[3-2 \mathrm{H}][\mathrm{Cl}]$, by $\mathrm{H}$-bonded water dimers. For distances and angles see text. $\mathrm{H}$ atoms, except those involved in $\mathrm{H}$ bonds are not represented for clarity.

${ }_{85}$ Solid state Structure of H-bonded networks: For all networks obtained upon combining the dicationic tectons $\mathbf{X}-2 \mathrm{H}^{+}(\mathrm{X}=2$ 4) with $\left[\mathrm{M}(\mathrm{CN})_{2}\right]^{-}(\mathrm{M}=\mathrm{Ag}$ or $\mathrm{Au})$ anions, the geometry of the organic tecton remains almost identical and thus will not be described.

$90 \quad\left[2-2 \mathbf{H}^{+}\right]\left[\mathbf{A g}(\boldsymbol{C N})_{2}\right]:$ The combination of $\mathbf{2}-2 \mathrm{H}^{+}$with $\left[\mathrm{Ag}(\mathrm{CN})_{2}\right]^{-}$anion leads to the formation of two different polymorphs $\alpha$ and $\beta$ (Fig. 3) displaying the same morphology. In both cases, the crystal is exclusively composed of $\mathbf{2}-2 \mathrm{H}^{+}$ cation and $\left[\mathrm{Ag}(\mathrm{CN})_{2}\right]^{-}$anion. By using different crystallisation 95 conditions (see experimental part), it was possible to obtain 
both polymorphs in the monocrystalline state.

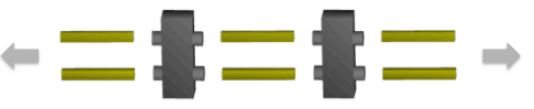

a)

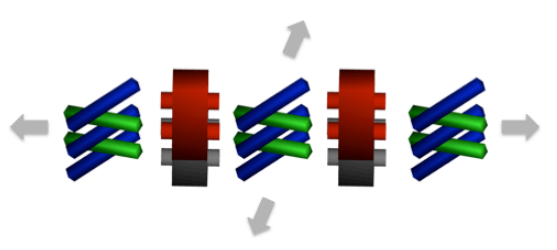

b)

Figure 3: Schematic representation of the polymorph $\alpha$ (a) and $\beta$ (b) observed for the combination of $\mathbf{X}-2 \mathrm{H}^{\cdot}(\mathrm{X}=1-4)$ with $\left[\mathrm{M}(\mathrm{CN})_{2}\right](\mathrm{M}=\mathrm{Ag}$ or

$5 \mathrm{Au}$ ). Whereas for the polymorph $\alpha$ the connectivity mode leads to the formation of a 1-D H-bonded network, for the polymorph $\beta$, it generates a 2-D H-bonded network. For the latter, $\left[\mathrm{M}(\mathrm{CN})_{2}\right]$ rod-type anions and cations are differentiated by colour ((blue and green) and (grey and red) respectively) for clarity.

10 The polymorph $\alpha$ (Fig. 3a) displays the same recognition pattern and connectivity as already observed for $1-2 \mathrm{H}^{+} .{ }^{15}$ For the anionic unit $\left[\mathrm{Ag}(\mathrm{CN})_{2}\right]^{-}$, the coordination geometry around the $\operatorname{Ag}(\mathrm{I})$ centre is slightly bent with $\mathrm{CAgC}$ angle of 173.01(13) $)^{\circ}$ and NCAg angle of $174.1(3)^{\circ}$ and $175.9(3)^{\circ}$. The

$15 \mathrm{Ag}-\mathrm{C}$ and $\mathrm{C} \equiv \mathrm{N}$ distances are in the 2.066(3) and 2.069(2) $\AA$ and 1.139(3) and 1.144(3) $\AA$ ranges respectively.

All the dicationic and monoanionic tectons are interconnected through strong H-bonds and electrostatic charge-charge interactions, leading thus to a neutral 1-D H-bonded network. 20 As expected and previously observed for $\left[1-2 \mathrm{H}^{+}\right]\left[\mathrm{M}(\mathrm{CN})_{2}\right](\mathrm{M}$ $=\mathrm{Ag}$ or $\mathrm{Au})^{15}$, the bridging of consecutive $2-2 \mathrm{H}^{+}$units by $\left[\mathrm{Ag}(\mathrm{CN})_{2}\right]^{-}$anions takes place through a monohapto mode of $\mathrm{H}$-bonding (one at each end of the anion) between $\mathrm{N}$ atoms of the anion acting as $\mathrm{H}$-bond acceptor and acidic protons of 2-

${ }_{25} 2 \mathrm{H}^{+}(\mathrm{N}-\mathrm{N}$ distances varying between $c a 2.87$ and $2.88 \AA)$

(Fig. 4a). Consequently, each $2-2 \mathrm{H}^{+}$is surrounded by four $\left[\mathrm{Ag}(\mathrm{CN})_{2}\right]^{-}$anions. Owing to the length of the spacer (phenyl group) connecting the two cyclic amidinium units, the two $\left[\mathrm{Ag}(\mathrm{CN})_{2}\right]^{-}$anions, disposed in a parallel fashion, located on 30 the same side of the organic tecton are in close proximity with a Ag-Ag distance of $c a 4.42 \AA$. The 1-D networks, running along the $c$ axis, are packed in a parallel fashion along the $a$ axis, with inter-network Ag-Ag distances of ca $6.80 \AA$ (Fig. $4 b)$. In marked contrast with the $1-2 \mathrm{H}^{+}$for which the 1-D 35 networks pack in parallel fashion along both other axes, for 2$2 \mathrm{H}^{+}$, although along $a$ axis the networks are packed in parallel fashion however, along $b$ axis, the 1D networks are tilted by $60.9^{\circ}$ with respect to those along the $a$ axis (Fig. 4c).

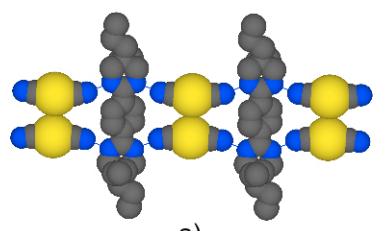

a)

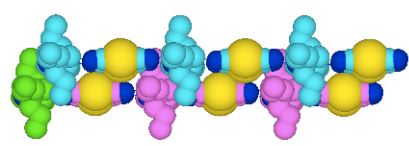

b)

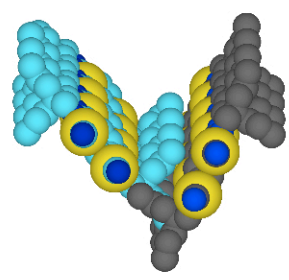

c)

$40 \quad$ Figure 4: Portion of the crystal structure of $\left[\mathrm{Ag}(\mathrm{CN})_{2}\right]_{2}\left[2-2 \mathrm{H}^{+}\right]$for the polymorph $\boldsymbol{\alpha}$ showing the formation of the 1D network along the $c$ axis (a), the packing of the networks along the $a$ axis (b) the tilt angle between two 1D network along the $b$ axis. For distances and angles see text. H atoms are not represented for clarity, unless involved in $\mathrm{H}$ bonding.

${ }_{45}$ The second polymorph $\beta$ displays a new type of connectivity pattern leading to a 2-D network (Fig. 3b). As for the polymorph $\alpha$ discussed above, the dicationic and mono anionic tectons are again interconnected through strong charge assisted $\mathrm{H}$-bonds with the $\mathrm{N}-\mathrm{N}$ distance varying between $\mathrm{ca}$ ${ }_{50} 2.85$ and $2.96 \AA$ (Fig. 5a). However, in marked contrast with the polymorph $\alpha$ for which each dianionic unit is connected to two (one on each side) tectons $2-2 \mathrm{H}^{+}$, surrounded by four $\left[\mathrm{Ag}(\mathrm{CN})_{2}\right]^{-}$anions (two on each side) disposed in parallel fashion leading thus to the formation of a 1-D neutral network ${ }_{55}$ (Fig. 3a and $4 \mathrm{a}$ ), in the case of the polymorph $\beta$, although the connectivity between anionic and cationic tectons also takes place through a bis monohapto mode of $\mathrm{H}$-bonding on each face of $2-2 \mathrm{H}^{+}$by two $\left[\mathrm{Ag}(\mathrm{CN})_{2}\right]^{-}$anions, the latter are not parallel but twisted (twist angle of $61.8^{\circ}$ ) (Fig. $3 \mathrm{~b}$ and $5 \mathrm{a}$ ). ${ }_{60}$ Consequently, each dication $2-2 \mathrm{H}^{+}$is connected to four organic tectons by four anionic units leading to a neutral 2-D network (Fig. 5b). Within the 2-D network, the distance between two consecutive silver cations is $3.29 \AA$. For the anionic unit $\left[\mathrm{Ag}(\mathrm{CN})_{2}\right]^{-}$, the coordination geometry around the ${ }_{65} \mathrm{Ag}(\mathrm{I})$ centre is linear $\left(\mathrm{CAgC}\right.$ angle of $180.000(1)^{\circ}$ and $\mathrm{NCAg}$ angle varying between $174.14(17)^{\circ}$ and $\left.178.7(2)^{\circ}\right)$ with $\mathrm{Ag}-\mathrm{C}$ and $\mathrm{C} \equiv \mathrm{N}$ distances varying between 2.066(2) and $2.0678(19) \AA$ and $1.144(2)$ and $1.147(3) \AA$ respectively). The $\mathrm{Ag}-\mathrm{Ag}$ distance between two consecutive planes is equal to $7011.34 \AA$. 

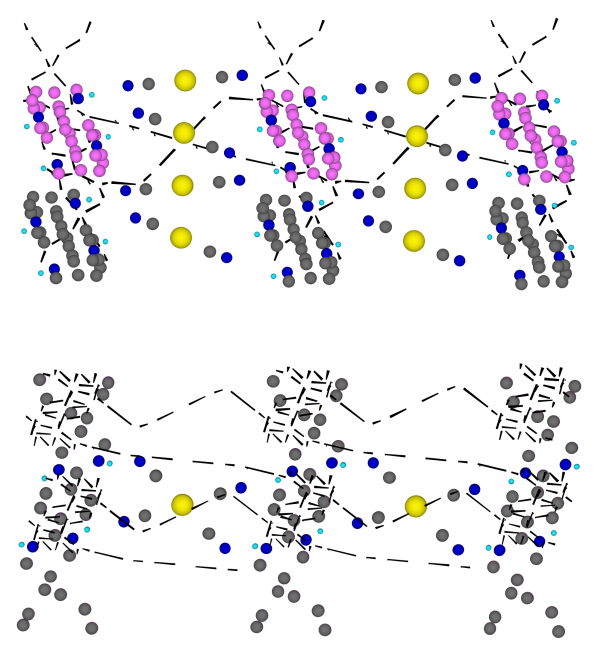

Figure 5 : Portions of the crystal structure of $\left[\operatorname{Ag}(\mathrm{CN})_{]_{2}}[2-2 \mathrm{H}]\right.$ for the polymorph $\beta$ showing the interconnection of consecutive cationic tectons by anionic units (a) and of the 2D network viewed in the (100) plane (b). 5 For the view presented in $\mathrm{a}$, the $\mathrm{Ag}$ atoms are eclipsed and consecutive $\left[\mathrm{Ag}(\mathrm{CN})_{3}\right]$ rod-type anions are located in consecutive planes (see figure $3 b)$. Cationic tectons belonging to consecutive planes are differentiated by colour. For distances and angles, see text. $\mathrm{H}$ atoms are not represented for clarity, unless involved in $\mathrm{H}$ bonding.

10 Although the formation of the pure polymorph $\beta$ could be established by PXRD which revealed a single crystalline phase (Fig. 6), the polymorph $\alpha$ could not be isolated as a pure polycrystalline material.

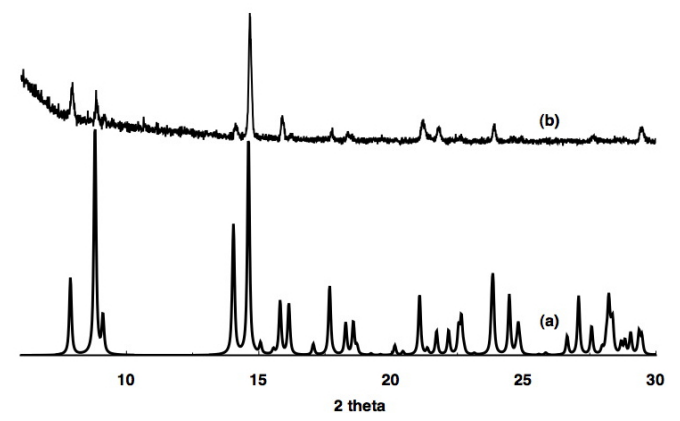

15 Figure 6: Comparison of the simulated (a) and recorded (b) PXRD patterns for the polymorph $\beta$ obtained upon combining $\left[\mathrm{Ag}(\mathrm{CN})_{2}\right]$ anion with tecton $2-2 \mathrm{H}^{+}$.

$\left[\mathrm{M}(\mathrm{CN})_{2}\right]_{2}\left[3-2 \mathrm{H}^{+}\right](\mathrm{M}=\mathrm{Ag}$ or $\mathrm{Au})$ : For combinations of tecton $3-2 \mathrm{H}^{+}$, with $\left[\mathrm{M}(\mathrm{CN})_{2}\right]^{-}(\mathrm{M}=\mathrm{Ag}$ or $\mathrm{Au})$, we were only 20 able to generate a 1-D $\mathrm{H}$ bonded network analogous to the polymorph obtained with $2-2 \mathrm{H}^{+}$combined with $\left[\mathrm{Ag}(\mathrm{CN})_{2}\right]$. Crystals were exclusively composed of $3-2 \mathrm{H}^{+}$and $\left[\mathrm{M}(\mathrm{CN})_{2}\right]^{-}$ $(\mathrm{M}=\mathrm{Ag}$ or $\mathrm{Au})$ and isostructural (see table 1). Despite many attempts, the 2D network could not be generated.

${ }_{25}$ The coordination geometry around the $\operatorname{Ag}(\mathrm{I})$ or $\mathrm{Au}(\mathrm{I})$ centre is almost linear (CMC angle of $178.26(12)^{\circ}$ for $\mathrm{M}=\mathrm{Ag}$ and of $179.63(16)^{\circ}$ for $\left.\mathrm{M}=\mathrm{Au}\right)$. The NCM angle is in the 177.5(3) 177.9(3) ${ }^{\circ}$ range for $\mathrm{M}=\mathrm{Ag}$ and 178.1(4)-178.2(4) ${ }^{\circ}$ for $\mathrm{M}=$ $\mathrm{Au}$. The M-C distance varies between 2.053(3) and 2.061(3) ${ }_{30} \AA$ for $\mathrm{M}=\mathrm{Ag}$ and between 1.969(4) and 1.971(4) $\AA$ for $\mathrm{M}=$ $\mathrm{Au}$. The $\mathrm{C} \equiv \mathrm{N}$ distance vary between 1.138(4) and 1.140(4) $\AA$ for $\mathrm{M}=\mathrm{Ag}$ and between 1.131(5) and 1.144(5) $\AA$ for $\mathrm{M}=\mathrm{Au}$ (Fig. 7). The 1-D network is formed by H-bonds between the anionic and cationic tectons with the $\mathrm{N}-\mathrm{N}$ distance of $c a 2.84$
35 and $2.86 \AA$ for $\mathrm{M}=\mathrm{Ag}$ and $c a 2.82$ and $2.85 \AA$ for $\mathrm{M}=\mathrm{Au}$. The M-M distance of $c a 4.92 \AA$ for $\mathrm{M}=\mathrm{Ag}$ and $c a 4.44 \AA$ for $\mathrm{M}=\mathrm{Au}$ is rather long. As observed for $\left[\mathrm{M}(\mathrm{CN})_{2}\right]_{2}\left[1-2 \mathrm{H}^{+}\right](\mathrm{M}$ $=\mathrm{Ag}, \mathrm{Au})^{15}$, the 1-D networks, running along the $c$ axis, are packed in a parallel fashion along the $a$ and $c$ axis, with Ag40 $\mathrm{Ag}$ and $\mathrm{Au}-\mathrm{Au}$ distances of $c a 6.49 \AA$ and $6.53 \AA$ respectively along $a$ and $c a 13.80 \AA$ and $13.75 \AA$ respectively along $c$.
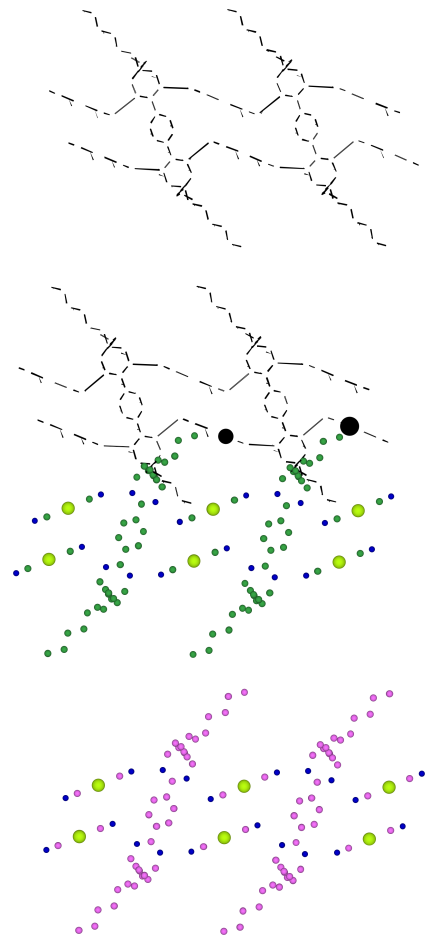

Figure 7: A portion of the structure of $\left[\mathrm{Ag}(\mathrm{CN})_{2}\right]_{2}\left[3-2 \mathrm{H}^{+}\right]$showing the parallel packing of consecutive H-bonded 1-D networks in the (100) plane 45 (a) and perpendicular to the $c$ axis (b). C atoms of consecutive networks are differentiated by colour for clarity (pink and green, and pink and blue). For distances and angles see text. $\mathrm{H}$ atoms are omitted for clarity.

$\left[\mathbf{M}(\mathrm{CN})_{2}\right]_{2}\left[4-2 \mathrm{H}^{+}\right](\boldsymbol{M}=\mathrm{Ag}$ or $\mathrm{Au})$ : The combination of 4$2 \mathrm{H}^{+}$with $\left[\mathrm{M}(\mathrm{CN})_{2}\right]^{-}(\mathrm{M}=\mathrm{Ag}$ or $\mathrm{Au})$ leads, as in the case of 50 tecton 2 , to two different connectivity patterns corresponding to polymorphs $\alpha$ and $\beta$ obtained with $2-2 \mathrm{H}^{+}$combined with $\left[\mathrm{Ag}(\mathrm{CN})_{2}\right]^{-}$anion. Whereas for $\left[\mathrm{Ag}(\mathrm{CN})_{2}\right]^{-}$anion a 2-D network is obtained, for $\left[\mathrm{Au}(\mathrm{CN})_{2}\right]^{-}$anion a 1-D network is formed. Attempts to generate the polymorph 1-D with ${ }_{55}\left[\mathrm{Ag}(\mathrm{CN})_{2}\right]^{-}$and polymorph 2-D with $\left[\mathrm{Au}(\mathrm{CN})_{2}\right]^{-}$were unsuccessful.

For the 1D network formed with $\left[\mathrm{Au}(\mathrm{CN})_{2}\right]^{-}$, the connectivity pattern is identical to the one observed for $2-2 \mathrm{H}^{+}$and $3-2 \mathrm{H}^{+}$ combined with the same anion (polymorph $\alpha$ ) (Fig. 3a). For ${ }_{60}$ the latter, an almost linear coordination geometry around the $\mathrm{Au}(\mathrm{I})$ centre was observed with $\mathrm{CAuC}$ angle varying between 177.3(4) ${ }^{\circ}$ and $\mathrm{NCAu}$ angles of $176.4(9)^{\circ}$ and $176.8(9)^{\circ}$. The $\mathrm{Au}-\mathrm{C}$ and $\mathrm{C} \equiv \mathrm{N}$ distances are in the 2.012(9)-2.015(9) $\AA$ and 1.115(9)-1.119(9) $\AA$ ranges respectively. As for the other 65 cases discussed above, anionic and cationic tectons are hydrogen bonded with the N-N distance varying between $\mathrm{ca}$ 2.82 and $2.84 \AA$. Within the 1-D network, the Au-Au distance of $c a 4.63 \AA$ is rather long (Fig. 8a). The 1-D networks, running along the $b$ axis, are packed in a parallel fashion 70 along the $a$ axis with a Au-Au distance of $c a 8.42 \AA$ (Fig. 8b). 
As for the $\mathbf{2}-2 \mathrm{H}^{+}$analogue, for $\mathbf{4}-2 \mathrm{H}^{+}$, although along $a$ axis the networks are packed in parallel fashion, they are not parallel along the $c$ axis with a tilt of $42.7^{\circ}$ with respect to those along the $b$ axis (Fig. 8c). Along the $c$ axis, the $\mathrm{Au}-\mathrm{Au}$ 5 distance is $c a 19.48 \AA$.

The dodecadecyl alkyl chains are interdigitated along both $a$ and $c$ axis (Fig. 8b and c).

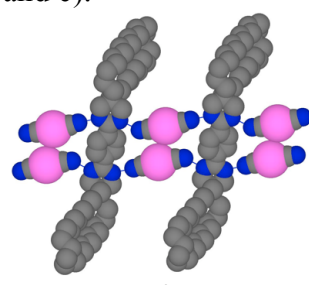

a)
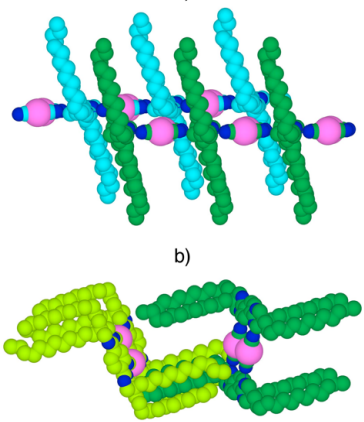

Figure 8 : Portions of the structure obtained upon combining 4-2H with $10 \quad\left[\mathrm{Au}(\mathrm{CN})_{2}\right]$ showing the connectivity pattern between the anionic and cationic tectons forming a 1-D H-bonded network running along the $b$ axis (a), the parallel packing of the 1-D networks along the $a$ axis (b) and along the $c$ axis (c). For distances and angles see text. For the representation of packing ( $\mathrm{a}$ and $\mathrm{b}$, the consecutive networks are differentiated by colour and $\mathrm{H}$ atoms are omitted for clarity.

For the $2 \mathrm{D}$ organisation obtained with $\left[\mathrm{Ag}(\mathrm{CN})_{2}\right]^{-}$, two of the four alkyl chains of $4-2 \mathrm{H}^{+}$are disordered. For the anionic partner, coordination geometry around the $\operatorname{Ag}(\mathrm{I})$ centre is linear $\left(\mathrm{CAgC}\right.$ angle of $\left.180.000(1)^{\circ}\right)$. NCAg angles of $20175.4(5)^{\circ}$ and $\left.179.0(5)^{\circ}\right)$ and $\mathrm{Ag}-\mathrm{C}$ and $\mathrm{C} \equiv \mathrm{N}$ distances in the 2.062(6)-2.065(5) $\AA$ and 1.120(5)-1.136(6) $\AA$ ranges are observed respectively. All dicationic and mono anionic units are interconnected through strong charge assisted H-bonds with N-N distance varying between $c a 2.83$ and $2.89 \AA$ (Fig. ${ }_{25} 9 \mathrm{a}$ ). The connectivity mode is analogous to the one observed for the polymorph $\beta$ obtained upon combining $2-2 \mathrm{H}^{+}$with $\left[\mathrm{Ag}(\mathrm{CN})_{2}\right]^{-}$(Fig. 3b). Consecutive $\left[\mathrm{Ag}(\mathrm{CN})_{2}\right]^{-}$anions twisted with an angle of $64.0^{\circ}$ (Fig. 9a). Within the 2-D network, a rather short Ag-Ag distance of $c a 3.32 \AA$ is observed (Fig. 30 9b). The shortest Ag-Ag distance between consecutive planes is equal to $c a 22.31 \AA$.
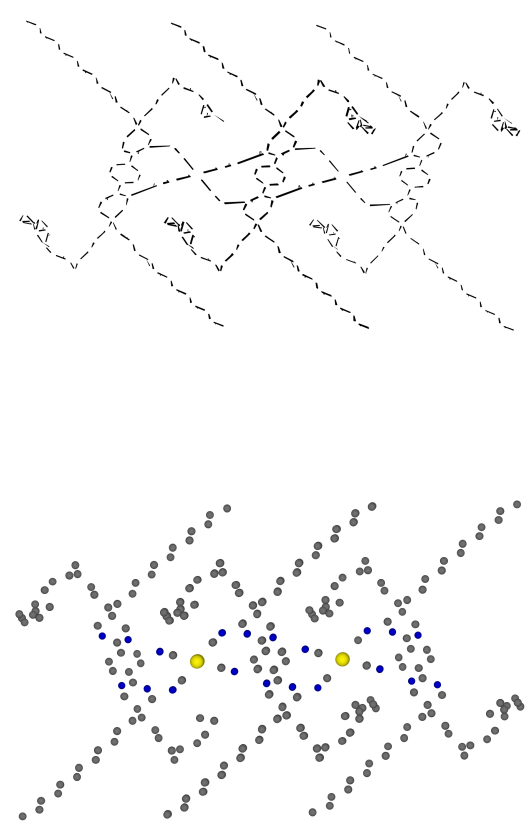

Figure 9 : Portions of the structure of the 2-D network formed between 4 $2 \mathrm{H}^{+}$and $\left[\mathrm{Ag}(\mathrm{CN})_{2}\right]$ showing views along (a) and perpendicular (b) to $\mathrm{Ag}$ 35 Ag axis. For distances and angles see text. $\mathrm{H}$ atoms are not represented for clarity.

The purity of both $\left[\mathrm{Ag}(\mathrm{CN})_{2}\right]_{2}\left[4-2 \mathrm{H}^{+}\right]$and $\left[\mathrm{Au}(\mathrm{CN})_{2}\right]_{2}\left[4-2 \mathrm{H}^{+}\right]$ crystalline materials was investigated by PXRD which revealed a good fit between the simulated and observed 40 patterns (Fig. 10).

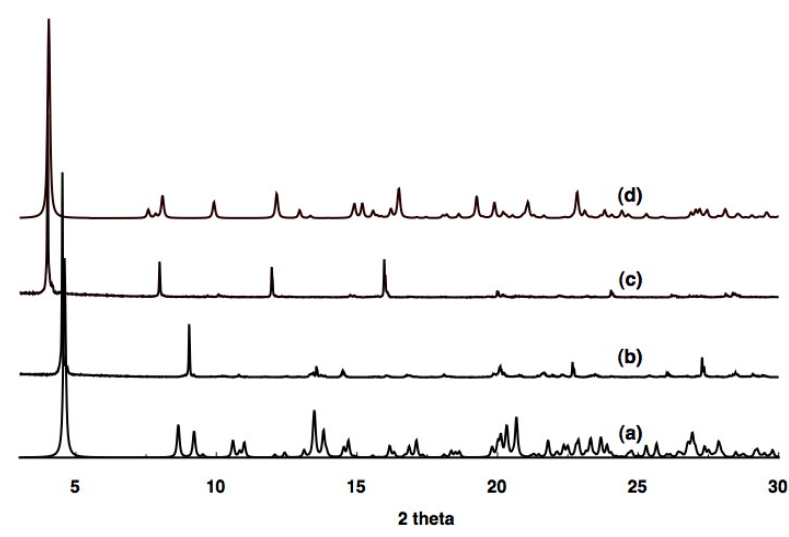

Figure 10: Powder X-ray diffraction study showing the comparison between simulated (a for $\left[\mathrm{Au}(\mathrm{CN})_{2}\right]_{2}\left[4-2 \mathrm{H}^{+}\right](1 \mathrm{D})$ and $\mathrm{d}$ for $\left[\mathrm{Ag}(\mathrm{CN})_{2}\right]_{2}[4-$ $\left.\left.2 \mathrm{H}^{+}\right](2 \mathrm{D})\right)$ and recorded $\left(\mathrm{b}\right.$ for $\left[\mathrm{Au}(\mathrm{CN})_{2}\right]_{2}\left[4-2 \mathrm{H}^{+}\right]$and $\mathrm{c}$ for $\left[\mathrm{Ag}(\mathrm{CN})_{2}\right]_{2}[4-$ $\left.\begin{array}{ll}45 & 2 \\ H^{+}\end{array}\right]$) patterns. Differences in peaks intensities are due to preferential orientations of the microcrystalline powders.

Effects of alkyl chain length on the packing: For all networks obtained upon combining $\mathrm{X}-2 \mathrm{H}^{+}(\mathrm{X}=1-4)$ with $\left[\mathrm{M}(\mathrm{CN})_{2}\right]^{-}(\mathrm{M}=\mathrm{Ag}$ or $\mathrm{Au})$ anions, the $\mathrm{M}-\mathrm{M}$ distance within 50 the network $\left(4.42 \AA\right.$ for $\left[\mathrm{Ag}(\mathrm{CN})_{2}\right]_{2}\left[2-2 \mathrm{H}^{+}\right]$(1D), $3.29 \AA$ for $\left[\mathrm{Ag}(\mathrm{CN})_{2}\right]_{2}\left[\mathbf{2}-2 \mathrm{H}^{+}\right](2 \mathrm{D}), 4.92 \AA$ for $\left[\mathrm{Ag}(\mathrm{CN})_{2}\right]_{2}\left[\mathbf{3}-2 \mathrm{H}^{+}\right](1 \mathrm{D})$, $4.44 \AA$ for $\left[\mathrm{Au}(\mathrm{CN})_{2}\right]_{2}\left[3-2 \mathrm{H}^{+}\right](1 \mathrm{D}), 4.62 \AA$ for $\left[\mathrm{Au}(\mathrm{CN})_{2}\right]_{2}[4-$ $\left.2 \mathrm{H}^{+}\right](1 \mathrm{D})$ and $\left.3.32 \AA\left[\mathrm{Ag}(\mathrm{CN})_{2}\right]_{2}\left[2-2 \mathrm{H}^{+}\right](2 \mathrm{D})\right)$ is almost not affected by the length of the alkyl chain. This is not surprising 55 and expected since this distance is imposed to a certain degree by the nature of the rigid aryl spacer connecting the two cyclic amidinium cations. 
For the $\left[\mathrm{M}(\mathrm{CN})_{2}\right]_{2}\left[\mathrm{X}-2 \mathrm{H}^{+}\right]\left(\mathrm{M}=\mathrm{Ag}\right.$ or $\mathrm{Au}$ and $\left.\mathrm{X}=1^{15}-3\right)$ systems for which 1-D arrays are packed in a parallel mode along both other axes, whereas the M-M distance between consecutive networks along $a$ axis does not reflect the 5 difference in size between $\mathrm{H}$ for $\mathbf{1}-2 \mathrm{H}^{+}$and hexyl chains for 3$2 \mathrm{H}^{+}$, along the $c$ axis, the $\mathrm{M}-\mathrm{M}$ distance increases with the size of the substituent $(7.15 \AA$ and $7.37 \AA$ for $\mathrm{M}=\mathrm{Ag}$, and $\mathrm{Au}$ respectively for $1-2 \mathrm{H}^{+}$and 13.80 and $13.75 \AA$ for $\mathrm{M}=\mathrm{Ag}$, and $\mathrm{Au}$ respectively for $\left.\mathbf{3}-2 \mathrm{H}^{+}\right)$. For $\left[\mathrm{Ag}(\mathrm{CN})_{2}\right]_{2}\left[\mathbf{2}-2 \mathrm{H}^{+}\right]$and $10\left[\mathrm{Au}(\mathrm{CN})_{2}\right]_{2}\left[4-2 \mathrm{H}^{+}\right]$, since the packing mode is different, this comparison can not be made.

It is worth noting that for both $\left[\mathrm{Ag}(\mathrm{CN})_{2}\right]_{2}\left[2-2 \mathrm{H}^{+}\right](1 \mathrm{D})$ and $\left[\mathrm{M}(\mathrm{CN})_{2}\right]_{2}\left[3-2 \mathrm{H}^{+}\right]$(1D), among the four alkyl chains, two (one on each extremity) are roughly within the main plane of 15 the unit whereas the other two, in trans configuration, are pointing almost perpendicular to the main plan of the tecton (tilt angles of $66.6^{\circ}, 66.5^{\circ}$ and $66.5^{\circ}$ for $\left[\mathrm{Ag}(\mathrm{CN})_{2}\right]_{2}\left[2-2 \mathrm{H}^{+}\right]$, $\left[\mathrm{Ag}(\mathrm{CN})_{2}\right]_{2}\left[3-2 \mathrm{H}^{+}\right]$and $\left[\mathrm{Au}(\mathrm{CN})_{2}\right]_{2}\left[3-2 \mathrm{H}^{+}\right]$respectively). This orientation of the chains is responsible for the increase of the 20 distance between consecutive 1-D networks along the $c$ axis. In marked contrast with $\left[\mathrm{M}(\mathrm{CN})_{2}\right]_{2}\left[\mathbf{2}-2 \mathrm{H}^{+}\right]$and $\left[\mathrm{M}(\mathrm{CN})_{2}\right]_{2}[\mathbf{3}-$ $\left.2 \mathrm{H}^{+}\right]$, in the case of the centrosymmetric $\left[\mathrm{Au}(\mathrm{CN})_{2}\right]_{2}\left[4-2 \mathrm{H}^{+}\right]$, the two alkyl chains located on each extremity of the tecton are syn oriented and almost perpendicular to the main plane of 25 the unit. This peculiar orientation of the $\mathrm{C} 12$ chains is probably responsible for the different packing mode observed. Luminescent properties: All the obtained crystalline materials exhibits blue luminescence upon irradiation at 370 $\mathrm{nm}$ (Fig. 11). The fluorescence may be due to both metal 30 centred transitions (closed-shell $\mathrm{d}^{10}-\mathrm{d}^{10}$ interactions) $)^{22}$ resulting from rather short the $\mathrm{M}-\mathrm{M}$ distance and metal to ligand charge transfer. Indeed, for the 1-D networks the M-M distance is in the 4.42-4.92 $\AA$ range. Even for the 2-D networks obtained with $2-2 \mathrm{H}^{+}$and $4-2 \mathrm{H}^{+}$, owing to their 35 peculiar connectivity pattern, a M-M distance in the 3.29-3.32 $\AA$ range is observed. It is worth noting that, for the 1-D systems, the blue luminescence observed is probably due to intermetallic interactions within networks imposed by the design of tectons $\left[\mathrm{X}-2 \mathrm{H}^{+}\right](\mathrm{X}=1-4)$. Indeed, the $\mathrm{M}-\mathrm{M}$ 40 distance between 1-D networks is too long to allow any interaction.

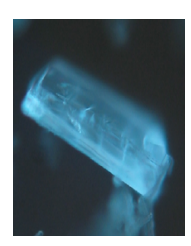

a

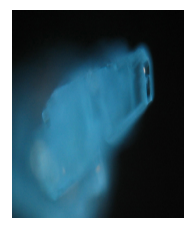

c

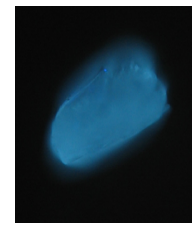

b

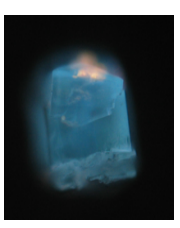

d
Figure 11: Photomicrograph showing the blue luminescence of the $\left[\mathrm{M}(\mathrm{CN})_{2}\right]_{2}\left[\mathbf{X}-2 \mathrm{H}^{+}\right]$crystals $(\mathrm{M}=\mathrm{Ag}$ or $\mathrm{Au}$ and $\mathrm{X}=2-4)$ when irradiated in the $370 \mathrm{~nm}$ region for a) $\left[\mathrm{Ag}(\mathrm{CN})_{2}\right]_{2}\left[\mathbf{2}-2 \mathrm{H}^{+}\right](1 \mathrm{D})$, b) $\left[\mathrm{Ag}(\mathrm{CN})_{2}\right]_{2}\left[\mathbf{2}-2 \mathrm{H}^{+}\right]$ $(2 \mathrm{D}), \mathrm{c})\left[\mathrm{Au}(\mathrm{CN})_{2}\right]_{2}\left[3-2 \mathrm{H}^{+}\right]$and d) $\left[\mathrm{Ag}(\mathrm{CN})_{2}\right]_{2}\left[4-2 \mathrm{H}^{+}\right]$

\section{Conclusions}

We have shown that combinations of bisamidinium dicationic tectons $\left[\mathrm{X}-2 \mathrm{H}^{+}\right](\mathrm{X}=2-4)$ with $\left[\mathrm{M}(\mathrm{CN})_{2}\right]^{-}(\mathrm{M}=\mathrm{Ag}$ or $\mathrm{Au})$ anions leads to the formation of crystalline materials resulting 50 from the interconnection of the cationic and anionic tectons by strong charge-assisted H-bonds. Whereas in the case of $\mathbf{2 -}$ $2 \mathrm{H}^{+}$two polymorphs corresponding to 1 - and 2-D H-bonded networks (polymorphs $\alpha$ and $\beta$ ) differing by the connectivity patterns between tectons have been obtained, for $3-2 \mathrm{H}^{+}$, only 55 a 1-D network was observed in the presence of $\left[\mathrm{M}(\mathrm{CN})_{2}\right]^{-}(\mathrm{M}$ $=\mathrm{Ag}$ or $\mathrm{Au})$ anions. For $4-2 \mathrm{H}^{+}$, whereas with $\left[\mathrm{Au}(\mathrm{CN})_{2}\right]^{-}$ anion a 1-D network was obtained, with $\left[\mathrm{Ag}(\mathrm{CN})_{2}\right]^{-}$anion the formation of a 2-D network was observed. The study of the role played by the size of substituents on the extremities of 60 cationic tectons $\left(\mathrm{H}\right.$ for $\mathbf{1}-2 \mathrm{H}^{+}$, propyl for $\mathbf{2}-2 \mathrm{H}^{+}$, hexyl for $\mathbf{3}-$ $2 \mathrm{H}^{+}$and dodecyl for $4-2 \mathrm{H}^{+}$) on the packing of 1-D networks revealed, as expected no effect on the M-M distance for metal centres located within the 1-D networks. Owing to the orientation of the alkyl chains for $2-2 \mathrm{H}^{+}$and $3-2 \mathrm{H}^{+}$, whereas ${ }_{65}$ for the packing of 1-D networks along $a$ axis, the M-M distance was not reflecting the size of the substituent, along the $c$ axis, a correlation was observed. The M-M distance is imposed in the case of the analogous 1-D networks by the aryl spacer connecting the two cyclic amidinium units. In the case 70 of 1-D networks, it is worth noting that the luminescence property observed for both metal centres $(\mathrm{Ag}(\mathrm{I})$ and $\mathrm{Au}(\mathrm{I}))$ is probably due to the controlled disposition of $\left[\mathrm{M}(\mathrm{CN})_{2}\right]^{-}$anions in close proximity resulting from specific recognition events taking place between anionic and cationic tectons. The 75 combination of other dicationic tectons with cyanometallate anions is currently under investigation.

\section{Acknowledgement}

University of Strasbourg, Institut Universitaire de France, CNRS and the Ministry of Education and Research are 80 acknowledged for financial support and for a scholarship to P. D.

\section{Experimental}

\section{Single-Crystal Studies.}

Data were collected at 173(2) K on a Bruker APEX8 CCD ${ }_{85}$ Diffractometer equipped with an Oxford Cryosystem liquid $\mathrm{N} 2$ device, using graphite-monochromated Mo-Ka $(1=$ 0.71073 ) radiation. For all structures, diffraction data were corrected for absorption and structural determination was achieved using the APEX (1.022) package. The hydrogen 90 atoms were introduced at calculated positions and not refined (riding model). ${ }^{23}$

\section{Powder diffraction studies (PXRD)}

Diagrams were collected on a Bruker D8 diffractometer using monochromatic $\mathrm{Cu}-\mathrm{K} \alpha$ radiation with a scanning range 95 between 3.8 and $30^{\circ}$ using a scan step size of $2^{\circ} / \mathrm{mn}$.

\section{Luminescent images}

Luminescence images have been obtained using the Zeiss 
Axioplan 2 microscope equipped with a Filter Set 024880029901-000 G $365 \mathrm{FT} 395 \mathrm{LP} 420(\mathrm{G}=$ excitation, $\mathrm{LP}=$ dichroic mirror).

\section{Synthesis}

${ }_{5}$ The synthesis of $\left[2-2 \mathrm{H}^{+}\right]\left[\mathrm{Cl}^{-}\right]_{2}$ has been already described. ${ }^{18}$ The chemicals purchased from commercial sources were used without further purification.

The synthesis of $\left[3-2 \mathrm{H}^{+}\right]\left[\mathrm{Cl}^{-}\right]_{2}$ and $\left[4-2 \mathrm{H}^{+}\right]\left[\mathrm{Cl}^{-}\right]_{2}$ have been achieved following the already described procedure ${ }^{18,24}$ for $10\left[2-2 \mathrm{H}^{+}\right]\left[\mathrm{Cl}^{-}\right]_{2}$ (scheme 1).

Synthesis of the dinitrile $6^{24}$ : A solution of malononitrile 5 (5 g, $75.7 \mathrm{mmol})$ in anhydrous THF $(100 \mathrm{ml})$ was added dropwise to a suspension of $\mathrm{NaH}(4.5 \mathrm{~g}, 189 \mathrm{mmol})$ in THF $(80 \mathrm{ml})$ at $0^{\circ} \mathrm{C}$ and the mixture was stirred for $2 \mathrm{hrs}$ before 115 bromohexane $(31.2 \mathrm{~g}, 189 \mathrm{mmol})$ dissolved in $40 \mathrm{ml}$ of dry THF was added. The mixture was refluxed for $26 \mathrm{hrs}$ under argon. The excess of sodium hydride was quenched with $\mathrm{MeOH}(15 \mathrm{ml})$ and solvents were evaporated. The product was extracted with $\mathrm{CH}_{2} \mathrm{Cl}_{2}(160 \mathrm{ml})$ and the organic layer was 20 washed with $\mathrm{H}_{2} \mathrm{O}(200 \mathrm{ml})$ and a saturated solution of $\mathrm{NaCl}$ (200 $\mathrm{ml}$ ) before it was dried over $\mathrm{MgSO}_{4}$ and evaporated. The residue was purified by column chromatography $\left(\mathrm{SiO}_{2}\right.$, cyclohexane) affording the desired dinitrile $\mathbf{6}$ as a yellowish oil in $27 \%$ yield. ${ }^{1} \mathrm{H}-\mathrm{NMR}\left(\mathrm{CDCl}_{3}, \delta \mathrm{ppm}\right): 0.89\left(\mathrm{t}, 6 \mathrm{H},{ }^{3} \mathrm{~J}=\right.$ $\left.{ }_{25} 6.3 \mathrm{~Hz}, \mathrm{CH}_{3}\right), 1.31\left(\mathrm{~m}, 12 \mathrm{H}, \mathrm{CH}_{2}\right), 1.68\left(\mathrm{~m}, 4 \mathrm{H}, \mathrm{CH}_{2}-\mathrm{CH}_{2}-\mathrm{C}\right)$, $1.91\left(\mathrm{~m}, 4 \mathrm{H}, \mathrm{CH}_{2}-\mathrm{C}\right) ;{ }^{13} \mathrm{C}-\mathrm{NMR}\left(\mathrm{CDCl}_{3}, \delta \mathrm{ppm}\right): 13.96$ $\left(\mathrm{CH}_{3}\right), 22.40,25.50,28.48,31.27,37.77\left(\mathrm{CH}_{2} n\right.$-hexyle $+\mathrm{C}$ quat.), $115.82(\mathrm{C} \equiv \mathrm{N})$.

Synthesis of the dinitrile $\mathbf{7}^{24}$ : A solution of malonitrile 5 (5.4 $30 \mathrm{~g}, 82 \mathrm{mmol})$ in anhydrous THF $(60 \mathrm{ml})$ was added dropwise to a suspension of $\mathrm{NaH}(4.3 \mathrm{~g}, 181 \mathrm{mmol})$ in THF $(80 \mathrm{ml})$ at 0 ${ }^{\circ} \mathrm{C}$ and the mixture stirred for $30 \mathrm{~min}$. 1-bromododecane (41 $\mathrm{g}, 164 \mathrm{mmol})$ dissolved in dry THF $(40 \mathrm{ml})$ was added and the mixture was first stirred during $2 \mathrm{hrs}$ at room temperature and 35 then refluxed for $17 \mathrm{hrs}$ under argon. The excess of sodium hydride was quenched with $\mathrm{MeOH}(15 \mathrm{ml})$ and the solvents were evaporated. The residue was suspended in water and the $\mathrm{pH}$ was adjusted to 1 with an $\mathrm{HCl}$ solution. The product was extracted with $\mathrm{Et}_{2} \mathrm{O}(3 \times 100 \mathrm{ml})$ and the organic layer washed 40 with $\mathrm{H}_{2} \mathrm{O}(100 \mathrm{ml})$ and a saturated solution of $\mathrm{NaCl}(100 \mathrm{ml})$ before it was dried over $\mathrm{MgSO}_{4}$ and evaporated. The residue was further washed with $\mathrm{CH}_{2} \mathrm{Cl}_{2}(100 \mathrm{ml})$ and water $(100 \mathrm{ml})$ before it was dried over $\mathrm{MgSO}_{4}$ and evaporated. The residue was purified by column chromatography $\left(\mathrm{SiO}_{2}\right.$, cyclohexane ${ }_{45} \rightarrow \mathrm{CH}_{2} \mathrm{Cl}_{2}$ ) affording the desired dinitrile 7 as a white solid in $74 \%$ yield. ${ }^{1} \mathrm{H}-\mathrm{NMR}\left(\mathrm{CDCl}_{3}, \delta \mathrm{ppm}\right): 0.88\left(\mathrm{t}, 6 \mathrm{H},{ }^{3} \mathrm{~J}=6.3\right.$ $\left.\mathrm{Hz}, \mathrm{CH}_{3}\right), 1.26\left(\mathrm{~m}, 36 \mathrm{H}, \mathrm{CH}_{2}\right), 1.65\left(\mathrm{~m}, 4 \mathrm{H}, \mathrm{CH}_{2}-\mathrm{CH}_{2}-\mathrm{C}\right)$, $1.90\left(\mathrm{~m}, 4 \mathrm{H}, \mathrm{CH}_{2}-\mathrm{C}\right) .{ }^{13} \mathrm{C}-\mathrm{NMR}\left(\mathrm{CDCl}_{3}, \delta \mathrm{ppm}\right): 14.18\left(\mathrm{CH}_{3}\right)$, 22.77, 25.63, 28.95, 29.24, 29.46, 29.61, 29.68, 31.99, 37.90 ${ }_{50}\left(\mathrm{CH}_{2}\right.$ n-dodecyle $+\mathrm{C}$ quat. $), 115.91(\mathrm{C} \equiv \mathrm{N})$.

Synthesis of the diamine $8^{24}$ : $\mathrm{A} \mathrm{BH}_{3}$ solution in THF $(1 \mathrm{~N}, 50$ $\mathrm{ml})$ was added dropwise to a solution of the dinitrile 6 (2.0 g, $8.5 \mathrm{mmol})$ in anhydrous THF $(50 \mathrm{ml})$. The reaction mixture was refluxed for $24 \mathrm{hrs}$ under argon. The excess of $\mathrm{BH}_{3}$ was 55 quenched carefully with water $(10 \mathrm{ml})$ and the solvents were evaporated. To the residue thus obtained, $100 \mathrm{ml}$ of a solution $\left(\mathrm{MeOH} 50 \%, \mathrm{H}_{2} \mathrm{O} 25 \%, \mathrm{HCl}(12 \mathrm{~N}) 25 \%\right)$ was added and the mixture refluxed overnight. After evaporating the solvents, an aqueous solution of $\mathrm{NaOH}$ was added dropwise until the $\mathrm{pH}$ 6013 was reached. The product was extracted several times with $\mathrm{CH}_{2} \mathrm{Cl}_{2}(3 \times 80 \mathrm{ml})$. The organic layer was further washed with $\mathrm{H}_{2} \mathrm{O}(80 \mathrm{ml})$, dried over $\mathrm{MgSO}_{4}$ and evaporated to dryness affording the diamine $\mathbf{8}$ as a colourless oil in $\mathrm{ca} 90 \%$ yield. The latter was directly used in the next step. ${ }^{1} \mathrm{H}-\mathrm{NMR}$ ${ }_{65}\left(\mathrm{CDCl}_{3}, \delta \mathrm{ppm}\right): 0.87\left(\mathrm{t}, 6 \mathrm{H},{ }^{3} \mathrm{~J}=6.5 \mathrm{~Hz}, \mathrm{CH}_{3}\right), 1.15,1.30(\mathrm{~m}$, $20 \mathrm{H}, \quad \mathrm{CH}_{2} n$-hexyle), $2.51 \quad\left(\mathrm{~s}, \quad 4 \mathrm{H}, \quad \mathrm{CH}_{2}-\mathrm{NH}_{2}\right) .{ }^{13} \mathrm{C}-\mathrm{NMR}$ $\left(\mathrm{CDCl}_{3}, \delta \mathrm{ppm}\right): 14.00\left(\mathrm{CH}_{3}\right), 22.62,22.82,30.24,31.82$, $32.49,40.27\left(\mathrm{CH}_{2} n\right.$-hexyle $+\mathrm{C}$ quat. $), 46.13\left(\mathrm{CH}_{2}-\mathrm{NH}_{2}\right)$.

Synthesis of the diamine 924: $\mathrm{A} \mathrm{BH}_{3}$ solution in THF $(1 \mathrm{~N}$, $70110 \mathrm{ml}$ ) was added dropwise to a solution of the dinitrile 7 (6 $\mathrm{g}, 15.8 \mathrm{mmol})$ in anhydrous THF $(50 \mathrm{ml})$. The reaction mixture was refluxed for $24 \mathrm{hrs}$ under argon. The excess of $\mathrm{BH}_{3}$ was quenched carefully with water $(20 \mathrm{ml})$ and the solvents were evaporated. To the residue was added to $200 \mathrm{ml}$ 75 of a mixture of $\mathrm{MeOH}(50 \%), \mathrm{H}_{2} \mathrm{O}(25 \%)$ and $\mathrm{HCl}(12 \mathrm{~N}$, $25 \%)$ and the mixture was refluxed $22 \mathrm{hrs}$. After evaporating the solvents, an aqueous solution of $\mathrm{NaOH}$ was added dropwise until the $\mathrm{pH}=13$ was reached. The product was extracted several times into $\mathrm{CH}_{2} \mathrm{Cl}_{2}(3 \times 100 \mathrm{ml})$. The organic 80 layer was further washed with $\mathrm{H}_{2} \mathrm{O}(10 \mathrm{ml})$, dried over $\mathrm{MgSO}_{4}$ and evaporated to dryness affording the diamine $\mathbf{9}$ as a colourless oil in $\mathrm{ca} 90 \%$ yield. The latter was directly used in the next step. ${ }^{1} \mathrm{H}-\mathrm{NMR}\left(\mathrm{CDCl}_{3}, \delta \mathrm{ppm}\right): 0.83\left(\mathrm{t}, 6 \mathrm{H},{ }^{3} \mathrm{~J}=6.5\right.$ $\left.\mathrm{Hz}, \mathrm{CH}_{3}\right), 1.21\left(\mathrm{~m}, 44 \mathrm{H}, \mathrm{CH}_{2} n\right.$-dodecyle), $2.50\left(\mathrm{~s}, 4 \mathrm{H}, \mathrm{CH}_{2}-\right.$ $\left.{ }_{85} \mathrm{NH}_{2}\right) .{ }^{13} \mathrm{C}-\mathrm{NMR}\left(\mathrm{CDCl}_{3}, \delta \mathrm{ppm}\right): 14.13\left(\mathrm{CH}_{3}\right), 22.72,22.92$, 29.39, 29.71, 30.57, 31.96, 32.60, $39.31\left(\mathrm{CH}_{2} n\right.$ - dodecyle $+\mathrm{C}$ quat.), $47.03\left(\mathrm{CH}_{2}-\mathrm{NH}_{2}\right)$.

Synthesis $\left[3-2 \mathrm{H}^{+}\right]\left[\mathrm{Cl}^{-}\right]_{2}$ : Diamine $8(5.0 \mathrm{~g}, 21.3 \mathrm{mmol})$ and 1,4-dicyanobenzene $(1.35 \mathrm{~g}, 10.5 \mathrm{mmol})$ and $\mathrm{P}_{2} \mathrm{~S}_{5}(100 \mathrm{mg})$ as 90 catalyst were mixed under argon and the temperature was first raised to $120{ }^{\circ} \mathrm{C}$ for $30 \mathrm{~min}$ and then to $180{ }^{\circ} \mathrm{C}$ for another 30 min. The mixture was dissolved in $\mathrm{CH}_{2} \mathrm{Cl}_{2}(100 \mathrm{ml})$ and acidified with $100 \mathrm{ml}$ of an aqueous $10 \% \mathrm{HCl}$ solution. The mixture was stirred vigorously and $\mathrm{Et}_{2} \mathrm{O}(150 \mathrm{ml})$ was added. 95 The solvents were evaporated and $\left[3-2 \mathrm{H}^{+}\right]\left[\mathrm{Cl}^{-}\right]_{2}$ was obtained as a white solid with an overall yield of $21 \%$. Mp: decomposition at $240{ }^{\circ} \mathrm{C} .{ }^{1} \mathrm{H}-\mathrm{NMR}\left(\mathrm{CD}_{3} \mathrm{OD}, \delta \mathrm{ppm}\right): 0.90(\mathrm{t}$, $\left.12 \mathrm{H},{ }^{3} \mathrm{~J}=6.5 \mathrm{~Hz}, \mathrm{CH}_{3}\right), 1.33\left(\mathrm{~m}, 88 \mathrm{H}, \mathrm{CH}_{2} n\right.$-hexyle), $3.38(\mathrm{~s}$, $\left.8 \mathrm{H}, \mathrm{CH}_{2}-\mathrm{NH}_{2}\right), 7.97$ (s, 4H, CH arom.); ${ }^{13} \mathrm{C}-\mathrm{NMR}\left(\mathrm{CD}_{3} \mathrm{OD}, \delta\right.$ $100 \mathrm{ppm})$ : $19.97\left(\mathrm{CH}_{3}\right), 22.2,29.5,30.6,31.4,32.7\left(\mathrm{CH}_{2} n\right.$-hexyle $+\mathrm{C}$ quat.), $47.7\left(\mathrm{CH}_{2}-\mathrm{NH}_{2}\right), 128.3(\mathbf{C H}$ arom.), $159.0(\mathrm{~N}-$ $\mathrm{C}=\mathrm{N})$. Elemental analysis: $\mathrm{C}_{38} \mathrm{H}_{68} \mathrm{~N}_{4} \mathrm{Cl}_{2} .2 \mathrm{H}_{2} \mathrm{O}$, calculated: $\mathrm{C}=$ $66.35 \%, \mathrm{H}=10.55 \%, \mathrm{~N}=8.14 \%$, found: $\mathrm{C}=66.56 \%, \mathrm{H}=$ $10.70 \%, \mathrm{~N}=7.88 \%$. IR $\left(\mathrm{cm}^{-1}\right): 2954,2932,2862,1516$, $1051469,1350,1328,1298,1187,984,853,832,723,799$. ES MS : $\mathrm{m} / \mathrm{z}: 290.29$, calculated $290.27\left(\left[3-2 \mathrm{H}^{+}\right], \mathrm{C}_{38} \mathrm{H}_{68} \mathrm{~N}_{4}\right)$, 579.54, calculated $579.54\left(\left[3-\mathrm{H}^{+}\right], \mathrm{C}_{38} \mathrm{H}_{67} \mathrm{~N}_{4}\right)$. Decomposition at $240{ }^{\circ} \mathrm{C}$

Synthesis $\left[4-2 \mathrm{H}^{+}\right]\left[\mathrm{Cl}^{-}\right]_{2}$ : Diamine $9(3.0 \mathrm{~g}, 7.32 \mathrm{mmol})$ and 110 1,4-dicyanobenzene (469 mg, $3.66 \mathrm{mmol})$ and $\mathrm{P}_{2} \mathrm{~S}_{5}(15 \mathrm{mg})$ as catalyst were mixed under argon and the temperature was first raised to $180{ }^{\circ} \mathrm{C}$ for $1 \mathrm{hr}$ and then to $230{ }^{\circ} \mathrm{C}$ during $1.5 \mathrm{hr}$. The mixture was dissolved in $\mathrm{CH}_{2} \mathrm{Cl}_{2}(80 \mathrm{ml})$ and acidified with $80 \mathrm{ml}$ of an aqueous solution of $\mathrm{HCl}(5 \%)$. The mixture was 115 stirred vigorously and $\mathrm{Et}_{2} \mathrm{O}(150 \mathrm{ml})$ was added. The solvents 
were evaporated and $\left[4-2 \mathrm{H}^{+}\right]\left[\mathrm{Cl}^{-}\right]_{2}$ was obtained as a white solid with an overall yield of $15 \%$. Mp: decomposition at 235 ${ }^{\circ} \mathrm{C} .{ }^{1} \mathrm{H}-\mathrm{NMR}\left(\mathrm{CDCl}_{3}, \delta \mathrm{ppm}\right): 0.87\left(\mathrm{t}, 12 \mathrm{H},{ }^{3} \mathrm{~J}=6.5 \mathrm{~Hz}, \mathrm{CH}_{3}\right)$, $1.21\left(\mathrm{~m}, 88 \mathrm{H}, \mathrm{CH}_{2}\right.$-dodecyle), 3.34 (s, $\left.8 \mathrm{H}, \mathrm{CH}_{2}-\mathrm{NH}_{2}\right), 8.46$ 5 (s, 4H, CH arom.), 10.67 (br, $4 \mathrm{H}, \mathrm{NH}) ;{ }^{13} \mathrm{C}-\mathrm{NMR}\left(\mathrm{CD}_{3} \mathrm{OD}, \delta\right.$ ppm) : $13.0\left(\mathrm{CH}_{3}\right), 22.3,29.1,29.3,29.7,30.6,31.6,32.6$ $\left(\mathrm{CH}_{2}\right.$ n-dodecyle); 128.3 ( $\mathrm{CH}$ arom.). Elemental analysis: $\mathrm{C}_{62} \mathrm{H}_{116} \mathrm{~N}_{4} \mathrm{Cl}_{2}$. $\mathrm{H}_{2} \mathrm{O}$ calculated: $\mathrm{C}=73.98 \%, \mathrm{H}=11.82 \%, \mathrm{~N}=$ $5.57 \%$, found: $\mathrm{C}=74.20 \%, \mathrm{H}=11.70 \%, \mathrm{~N}=5.13 \%$. IR $10\left(\mathrm{~cm}^{-1}\right): 2957,2929,2852,1464,1331,1293,1188,1100$, 1023, 990, 858, 841, 698. ES MS : m/z : 458.46, calculated $456.46\left(\left[4-2 \mathrm{H}^{+}\right], \mathrm{C}_{62} \mathrm{H}_{116} \mathrm{~N}_{4}\right), 915.91$, calculated 915.91 ([4$\left.\left.\mathrm{H}^{+}\right], \mathrm{C}_{62} \mathrm{H}_{115} \mathrm{~N}_{4}\right)$. Decomposition at $235^{\circ} \mathrm{C}$.

\section{Crystallisation}

15 Crystallisation of $\left[3-2 \mathrm{H}^{+}\right]\left[\mathrm{Cl}^{-}\right]_{2}$ : Colourless crystals of [3$\left.2 \mathrm{H}^{+}\right]\left[\mathrm{Cl}^{-}\right]_{2}$ of molecular formula $\mathrm{C}_{38} \mathrm{H}_{68} \mathrm{~N}_{4} \mathrm{Cl}_{2} \cdot 2 \mathrm{H}_{2} \mathrm{O}$ were obtained by slow evaporation of a solution of $\left[3-2 \mathrm{H}^{+}\right]\left[\mathrm{Cl}^{-}\right]_{2}(4$ $\mathrm{mg})$ dissolved in $\mathrm{EtOH}(5 \mathrm{ml})$.

Formation of crystals of $\left[2-2 \mathrm{H}^{+}\right]\left[\mathrm{Ag}(\mathrm{CN})_{2}^{-}\right]_{2}$ (polymorph

$20 \alpha)$ : Colourless crystals were obtained upon slow evaporation of a solution of $\left[2-2 \mathrm{H}^{+}\right]\left[\mathrm{Cl}^{-}\right]_{2}(4 \mathrm{mg})$ and $\mathrm{KAg}(\mathrm{CN})_{2}(3 \mathrm{mg})$ dissolved in EtOH $(5 \mathrm{ml})$. Yield: $c a$. $65 \%$. IR: $\mathrm{v}_{\mathrm{C} \equiv \mathrm{N}}=2134$ $\mathrm{cm}^{-1}$. Decomposition above $280{ }^{\circ} \mathrm{C}$.

Formation of crystals of $\left[2-2 \mathrm{H}^{+}\right]\left[\mathrm{Ag}(\mathrm{CN})_{2}^{-}\right]_{2}$ (polymorph $\left.{ }_{25} \boldsymbol{\beta}\right)$ : In a crystallization tube ( $4 \mathrm{~mm}$ diameter) equipped with a stopper, upon slow diffusion at $4{ }^{\circ} \mathrm{C}$, through a layer of distilled $\mathrm{H}_{2} \mathrm{O}(0.6 \mathrm{ml})$, of a $\mathrm{MeOH}$ solution $(0.4 \mathrm{ml})$ of [2$\left.2 \mathrm{H}^{+}\right]\left[\mathrm{Cl}^{-}\right]_{2}(4 \mathrm{mg})$ into an aqueous solution $(0.6 \mathrm{ml})$ of $\mathrm{KAg}(\mathrm{CN})_{2}(4 \mathrm{mg})$, colourless crystals of $\left[2-2 \mathrm{H}^{+}\right]\left[\mathrm{Ag}(\mathrm{CN})_{2}{ }^{-}\right]_{2}$ 30 were obtained after two weeks. Yield: $c a$. $75 \%$. IR: $v_{\mathrm{C} \equiv \mathrm{N}}=$ $2137 \mathrm{~cm}^{-1}$. Decomposition above $280{ }^{\circ} \mathrm{C}$.

Formation of crystals of $\left[3-2 \mathrm{H}^{+}\right]\left[\mathrm{Au}(\mathrm{CN})_{2}^{-}\right]_{2}$ : A saturated $\mathrm{MeOH}$ solution $(5 \mathrm{ml})$ of $\mathrm{KAu}(\mathrm{CN})_{2}(12 \mathrm{mg})$ was added to a saturated $\mathrm{MeOH}$ solution $(5 \mathrm{ml})$ of $\left[3-2 \mathrm{H}^{+}\right]\left[\mathrm{Cl}^{-}\right]_{2}(10 \mathrm{mg})$. The 35 white precipitate thus obtained was filtered after one hour and redissolved in a minimum of $i \mathrm{Pr}-\mathrm{OH}$. Colourless crystals of $\left[3-2 \mathrm{H}^{+}\right]\left[\mathrm{Au}(\mathrm{CN})_{2}{ }^{-}\right]_{2}$ appeared after several days upon slow evaporation at room temperature. Yield: $c a$. 45\%. Elemental analysis: $\mathrm{C}_{42} \mathrm{H}_{68} \mathrm{Au}_{2} \mathrm{~N}_{4}$, calculated: $\mathrm{C}=49.31 \%, \mathrm{H}=6.70 \%$, ${ }_{40} \mathrm{~N}=5.48 \%$, found: $\mathrm{C}=50.11 \%, \mathrm{H}=6.54 \%, \mathrm{~N}=4.9 \%$. IR: $v_{\mathrm{C} \equiv \mathrm{N}}=2156 \mathrm{~cm}^{-1}$. Decomposition above $300{ }^{\circ} \mathrm{C}$.

Formation of crystals of $\left[3-2 \mathrm{H}^{+}\right]\left[\mathbf{A g}(\mathbf{C N})_{2}^{-}\right]_{2}$ : The same procedure as for $\left[3-2 \mathrm{H}^{+}\right]\left[\mathrm{Au}(\mathrm{CN})_{2}{ }^{-}\right]_{2}$ was applied using $12 \mathrm{mg}$ of $\mathrm{KAg}(\mathrm{CN})_{2}$. Yield ca. $70 \%$. IR: $v_{\mathrm{C} \equiv \mathrm{N}}=2138 \mathrm{~cm}^{-1}$.

${ }_{45}$ Decomposition above $300{ }^{\circ} \mathrm{C}$.

Formation of crystals of $\left[4-2 \mathrm{H}^{+}\right]\left[\mathrm{Au}(\mathrm{CN})_{2}^{-}\right]_{2}$ (polymorph $\alpha)$ : A saturated $\mathrm{MeOH}$ solution $(5 \mathrm{ml})$ of $\mathrm{KAu}(\mathrm{CN})_{2}(10 \mathrm{mg})$ was added to a saturated $\mathrm{MeOH}$ solution $(5 \mathrm{ml})$ of $\left[4-2 \mathrm{H}^{+}\right]\left[\mathrm{Cl}^{-}\right.$ ]$_{2}(10 \mathrm{mg})$. The white precipitate thus formed was filtered 50 after one hour and redissolved in a minimum of $\mathrm{MeOH}$. Colourless crystals of $\left[4-2 \mathrm{H}^{+}\right]\left[\mathrm{Au}(\mathrm{CN})_{2}{ }^{-}\right]_{2}$ appeared after $\mathrm{ca} 2$ weeks upon evaporation at room temperature. Yield: $c a$. 55\%. Elemental analysis: $\mathrm{C}_{66} \mathrm{H}_{116} \mathrm{Au}_{2} \mathrm{~N}_{8}$, calculated: $\mathrm{C}=56.00 \%, \mathrm{H}$ $=8.26 \%, \mathrm{~N}=7.92 \%$, found: $\mathrm{C}=56.41 \%, \mathrm{H}=7.97 \%, \mathrm{~N}=$ ${ }_{55} 7.28 \%$. IR: $v_{\mathrm{C} \equiv \mathrm{N}}=2154 \mathrm{~cm}^{-1}$.

Decomposition above $300{ }^{\circ} \mathrm{C}$.

Formation of crystals of $\left[4-2 \mathrm{H}^{+}\right]\left[\mathrm{Ag}(\mathrm{CN})_{2}^{-}\right]_{2}$ (polymorph $\beta)$ : The same procedure as for $\left[4-2 \mathrm{H}^{+}\right]\left[\mathrm{Au}(\mathrm{CN})_{2}{ }^{-}\right]_{2}$ was applied using $10 \mathrm{mg}$ of $\mathrm{KAg}(\mathrm{CN})_{2}$. Yield: $c a$. 55\%. Elemental 60 analysis: $\mathrm{C}_{66} \mathrm{H}_{116} \mathrm{Ag}_{2} \mathrm{~N}_{8}$, calculated: $\mathrm{C}=64.06 \%, \mathrm{H}=9.45 \%$, $\mathrm{N}=9.06 \%$, found: $\mathrm{C}=63.26 \%, \mathrm{H}=8.86 \%, \mathrm{~N}=8.91$ $\%$.Yield : $c a .75 \%$. IR: $v_{\mathrm{C} \equiv \mathrm{N}}=2135 \mathrm{~cm}^{-1}$.

Decomposes above $300{ }^{\circ} \mathrm{C}$.

\section{Notes and references}

${ }_{65}{ }^{a}$ Laboratoire de Chimie de Coordination Organique, UMR CNRS-UdS

7140, Université de Strasbourg, Institut Le Bel,

4, rue Blaise Pascal, F-67000 Strasbourg, France

CCDC reference numbers 790491 - 790497. For crystallographic data in CIF or other electronic format see DOI: 10.1039/b000000x/

70

1 (a) S. Mann, Nature, 1993, 365, 499; (b) J. D. Wuest Chem. Comm., 2005, 5830; (c) M. W. Hosseini Acc. Chem. Res., 2005, 38, 313.

2 J.-M. Lehn, Supramolecular Chemistry, Concepts and Perspectives, VCH, Weinheim, 1995.

3 M. W. Hosseini, Chem. Comm., 2005, 582.

4 M. W. Hosseini CrystEngComm, 2004, 6, 318.

5 J. D. Dunitz, Pure Appl. Chem. 1991, 63, 177.

6 M. Simard, D. Su, J. D. Wuest J. Am. Chem. Soc., 1991, 113, 4696.

7 (a) M. C. Etter Acc. Chem. Res., 1990, 23, 120; (b) G. A. Jeffrey An Introduction to Hydrogen Bonding, Oxford University Press, Oxford, 1997; (c) R.Taylor, O. Kennard Acc. Chem. Res., 1984, 17, 320 ; d) C. B. Aakeröy, K. R. Seddon, Chem. Soc. Rev. 1993, 22, 397; e) S. Subramanian, M. J. Zaworotko, Coord. Chem. Rev. 1994, 137, 357; f) J. C. MacDonald, G. M. Whitesides, Chem. Rev. 1994, 94, 2383; g) G. R. Desiraju Angew. Chem. Int. Ed. Engl. 1995, 34, 2311.

8 (a) M. D.Ward Chem. Commun., 2005, 5838; (b) M. D.Ward, Molecular networks, Structure and Bonding, Springer, 2009, Eds M. W. Hosseini. (c) G. R. Lewis, A. G. Orpen, Chem. Commun., 1998, 1873 ; (d) A. Angeloni, P. C. Crawford, A. G. Orpen, T. J. Podesta, B. J. Shore, Chem. Eur. J., 2004, 10, 3783.

9 O. Félix, M. W. Hosseini, A. De Cian, J. Fischer New J. Chem., 1998, 22, 1389

10 O. Félix, M. W. Hosseini, A. De Cian, J. Fischer New J. Chem., 1997, 21, 285.

11 M. W. Hosseini Coord. Chem. Rev., 2003, 240, 157.

12 G.Marinescu, S. Ferlay, N. Kyritsakas, M.W. Hosseini, Dalton Trans., 2008, 615 .

13 C. Paraschiv, S. Ferlay, N. Kyritsakas, J-M. Planeix, M. Andruh, Rev Roum. Chim., 2007, 52, 101.

14 (a) S. Ferlay, V. Bulach, O. Félix, M. W. Hosseini, J.-M. Planeix, N. Kyritsakas, CrystEngComm, 2002, 447; (b) S. Ferlay, R. Holakovsky, M. W. Hosseini, J.-M. Planeix, N. Kyritsakas, Chem. Comm, 2003, 1224; (c) P. Dechambenoit, S. Ferlay, M. W. Hosseini, N. Kyritsakas, Chem. Commun., 2007, 4626.

15 C. Paraschiv, S. Ferlay, V. Bulach, J-M. Planeix Chem. Commun., 2004, 2270 .

16 P. Dechambenoit, S. Ferlay, M. W. Hosseini, N. Kyritsakas $J$. Am. Chem. Soc., 2008, 130, 17106.

17 P. Dechambenoit, S. Ferlay, B. Donnio, D. Guillon, M. W. Hosseini Chem. Commun., 2010, accepted, DOI:10.1039/C0CC03970E.

18 P. Dechambenoit, S. Ferlay, M. W. Hosseini, J.-M. Planeix, N. Kyritsakas, New. J. Chem., 2006, 30, 1403.

19 (a) P. Dechambenoit, S. Ferlay, M. W. Hosseini, N. Kyritsakas Chem. Commun., 2009, 6798; (b) P. Dechambenoit, S. Ferlay, M. W. Hosseini, N. Kyritsakas Chem. Commun., 2010, 868.

20 L. Van Haverbeke, H. O. Desseyn, B. J. Van Der Veken, M. A. Herman, Journal of Molecular Structure, 1975, 25, 53.

21 A. B. P. Lever, B. S. Ramaswamy, S. H. Simonsen, L. K. Thompson, Can. J. Chem., 1970, 48, 3076.

22 (a) H. Schmidbaur Chem. Soc. Rev., 1995, 24, 391; (b) P. Pyykkö Chem. Rev., 1997, 97, 597.

23 G. M. Sheldrick, Programs for the Refinement of Crystal Structures, University of Göttingen, Göttingen, Germany, 1996.

24 O. Félix, PhD Thesis, 1999, Université Louis Pasteur, Strasbourg. 
Table 1. Crystallographic Parameters (wavelength $=0.71073 \AA$, at $173 \mathrm{~K})$ for $\left[\mathrm{X}-2 \mathrm{H}^{+}\right](\mathrm{X}=2-4)$ combined with $\mathrm{Cl}^{-}, \mathrm{Au}(\mathrm{CN})_{2}^{-}$or $\mathrm{Ag}(\mathrm{CN})_{2}^{-}$.

Formula

Molecular weight

Crystal system

Space group

$\mathrm{a}(\AA)$

$\mathrm{b}(\AA)$

$\mathrm{c}(\AA)$

$\alpha(\operatorname{deg})$

$\beta(\operatorname{deg})$

$\gamma(\operatorname{deg})$

$\mathrm{V}\left(\AA^{3}\right)$

Z

Colour

Crystal dim (mm)

$D_{\text {calc }}\left(\mathrm{gcm}^{-3}\right)$

$\mathrm{F}(000)$

$\mu\left(\mathrm{mm}^{-1}\right)$

Number of data meas.

Number of data with $\mathrm{I}>2 \sigma(\mathrm{I})$

$\mathrm{R}$

$\mathrm{R}_{\mathrm{W}}$

GOF

Largest peak in final difference $\left(\mathrm{e} \AA^{-3}\right)$

$\left[3-2 \mathrm{H}^{+}\right]\left[\mathrm{Cl}^{-}\right]_{2}(1 \mathrm{D})$
$\mathrm{C}_{38} \mathrm{H}_{68} \mathrm{~N}_{4} \mathrm{Cl}_{2}, 2\left(\mathrm{H}_{2} \mathrm{O}\right)$
687.90
Triclinic
$\mathrm{P}-1$
$9.2183(7)$
$9.5015(7)$
$24.6412(18)$
$83.832(3)$
$81.225(2)$
$76.505(3)$
$2068.3(3)$
2
colourless
$0.20 \times 0.15 \times 0.15$
1.105
756
0.192
17654

8857 [R(int) $=0.0433]$

$\mathrm{R}_{1}=0.0562$,

$\mathrm{wR}_{2}=0.1197$

$\mathrm{R}_{1}=0.1236$,

$\mathrm{wR}_{2}=0.1466$

1.025

0.542 and -0.547 $\left[2-2 \mathrm{H}^{+}\right]\left[\mathrm{Ag}(\mathrm{CN})_{2}^{-}\right]_{2}$ (1D)

$\mathrm{C}_{30} \mathrm{H}_{44} \mathrm{Ag}_{2} \mathrm{~N}_{8}$

732.47

Monoclinic

$\mathrm{P} 2(1) / \mathrm{c}$

6.7993(4)

$19.1350(10)$

12.7204(6)

90

94.261(2)

90

1650.41(15)

2

colourless

1.474

748

1.218

9385

$3700[\mathrm{R}(\mathrm{int})=0.0381]$

$\mathrm{R}_{1}=0.0315$,

$\mathrm{wR}_{2}=0.0511$

$\mathrm{R}_{1}=0.0566$,

$\mathrm{wR}_{2}=0.0540$

1.065

0.989 and -0.604
$0.20 \times 0.06 \times 0.05$ $\left[2-2 \mathrm{H}^{+}\right]\left[\mathrm{Ag}(\mathrm{CN})_{2}^{-}\right]_{2}(2 \mathrm{D})$

$\mathrm{C}_{30} \mathrm{H}_{44} \mathrm{Ag}_{2} \mathrm{~N}_{8}$

732.47

Triclinic

P-1

6.5879(2)

11.3381(4)

12.2853(4)

$112.8290(10)$

$91.8580(10)$

104.2740(10)

$811.18(5)$

1

colourless

$0.08 \times 0.04 \times 0.01$

1.499

374

1.239

11943

$3686[\mathrm{R}(\mathrm{int})=0.0282]$

$\mathrm{R}_{1}=0.0225$,

$\mathrm{wR}_{2}=0.0552$

$\mathrm{R}_{1}=0.0303$,

$\mathrm{wR}_{2}=0.0587$

1.020

0.416 and -0.404 $\left[3-2 \mathrm{H}^{+}\right]\left[\mathrm{Ag}(\mathrm{CN})_{2}\right]_{2}(1 \mathrm{D})$

$\mathrm{C}_{42} \mathrm{H}_{68} \mathrm{Ag}_{2} \mathrm{~N}_{4}$

900.78

Triclinic

P-1

6.4924(4)

13.0691(8)

$13.8015(7)$

90.224(2)

95.777(2)

98.978(2)

1150.60(12)

1

colourless

$0.04 \times 0.04 \times 0.03$

1.300

470

0.887

9194

$5244[\mathrm{R}($ int $)=0.0322]$

$\mathrm{R}_{1}=0.0393$,

$\mathrm{wR}_{2}=0.0959$

$\mathrm{R}_{1}=0.0594$,

$\mathrm{wR}_{2}=0.1032$

1.028

0.702 and -0.401 $\left[3-2 \mathrm{H}^{+}\right]\left[\mathrm{Au}(\mathrm{CN})_{2}\right]_{2}(1 \mathrm{D})$

$\mathrm{C}_{42} \mathrm{H}_{68} \mathrm{Au}_{2} \mathrm{~N}_{4}$

1078.98

Triclinic

P-1

6.5286(13)

12.843(3)

13.746(3)

89.31(3)

83.39(3)

$81.26(3)$

1131.6(4)

1

colourless

$0.06 \times 0.06 \times 0.05$

1.583

534

6.512

12977

$6275[\mathrm{R}(\mathrm{int})=0.0353]$

$\mathrm{R}_{1}=0.0340$,

$\mathrm{wR}_{2}=0.0690$

$\mathrm{R}_{1}=0.0512$,

$\mathrm{wR}_{2}=0.0733$

1.021

1.981 and -1.224
$[4-2$ 
